\title{
HELICOBACTER PYLORI ERADICATION WITH BETA CAROTENE, ASCORBIC ACID AND ALLICIN
}

\author{
Cem Koçkar, Mustafa Öztürk, Nüket Bavbek \\ Fatih University Medical School, Ankara, Turkey: Department of Gastroenterology \\ Summary: In this study, in vivo effectiveness of ascorbic acid (AA), beta carotene (BC) and allicin in HP eradication were \\ evaluated. 210 patients who are HP positive in biopsy were involved in this study. The patients randomised to seven treat- \\ ment groups (each group consisting of 30 patients). The first group was given standard eradication treatment (lansapra- \\ sol $30 \mathrm{mg}$ bid, clarithromycin $500 \mathrm{mg}$ bid, amoxicillin $1 \mathrm{~g}$ bid for 14 days). Second group received AA $1000 \mathrm{mg} /$ day in \\ addition to the standard treatment. Third group received only AA $1000 \mathrm{mg}$ /day for 14 days. Fourth group was treated with \\ standard regiment plus $120 \mathrm{mg} /$ day BC. Fifth group was given only BC $120 \mathrm{mg} /$ day for 14 days. Sixth group was given stan- \\ dard regiment and allicin $4200 \mu \mathrm{g} /$ day. Seventh group received only Allicin $1200 \mu \mathrm{g} /$ day for 14 days. The eradication was \\ achieved in $20(66.6 \%)$ in group I, $15(50 \%)$ in group II, 3 (10\%) in group III, $15(50 \%)$ in group IV, 0 (0 \%) in group \\ V, $27(90 \%)$ in group VI and 7 (23.3\%) in group VII. Allicin seemed to be potentially effective agent for HP eradication \\ but ascorbic acid, beta caroten was found to be ineffective.
}

Key words: Helicobacter Pylori; Allicin; Ascorbic Acid; Beta Carotene

\section{Introduction}

Helicobacter pylori (HP) is one of the most common infectious agents and associated with numerous gastrointestinal system disorders (12). It is a known risk factor for gastric cancer (18). Eradication of HP not only provides symptomatic relief in most patients but also prevents subsequent complications (9).

Effectiveness of several double or triple antibiotic combinations with concurrent proton-pump inhibitors were studied and success rates reaches $80-95 \%$ in some regiments $(11,16)$. Cost effectiveness of drug therapy is an important issue particularly in developing countries where HP prevalence is extremely high (3).

HP induces oxidant stress on gastric mucosa. HP colonisation was shown to reduce gastric antioxidant (e.g. ascorbic acid) levels (22). On the other hand in vitro studies ascorbic acid (AA) was proved to be bactericidal for HP (23). In this study, in vivo effectiveness of AA, and two other antioxidants - beta carotene (BC) and Allicin - in HP eradication were evaluated.

\section{Material and Methods}

\section{Study group}

Two hundred and ten patients (113 female, 97 male; mean age $\pm \mathrm{SD}, 38 \pm 10$ years) who are HP positive in biopsy were involved in this study. The patients randomised to seven treatment groups (each group consisting of 30 pati- ents). Informed consent was taken in each patient. The first group was given standard eradication treatment (lansaprazole $30 \mathrm{mg}$ bid, claritromisin $500 \mathrm{mg}$ bid, amoxicilline $1 \mathrm{~g}$ bid for 14 days). Second group received AA $1000 \mathrm{mg} /$ day in addition to the standard treatment. Third group received only AA $1000 \mathrm{mg} /$ day for 14 days. Fourth group was treated with standard regiment plus $120 \mathrm{mg} /$ day BC. Fifth group was given only BC $120 \mathrm{mg} /$ day for 14 days. Sixth group was given standard regiment and Allicin $1200 \mu \mathrm{g} /$ day (Cirkulin dragé, $0.3 \mathrm{mg}$, Munir Sahin). Seventh group received only Allicin $4200 \mu \mathrm{g} /$ day for 14 days.

Endoscopic examination of the patients was conducted before and four weeks after the treatments by the same blinded endoscopist. Four biopsies from antrum and two biopsies from corpus were taken endoscopically in each patients. Biopsy specimens were painted with Giemsa for the detection of HP. The same expert who was blinded to the clinical data of the patients evaluated histologic specimens. For semiquantitative grading of presence of HP, the following criteria were used: Grade 0: no bacteria was detected; grade I: sporadic bacteria observed; grade II: many bacteria seen in most microscopic fields at high power magnification (x400); grade III: clusters of microorganisms were found in the superficial mucus layer in all fields examined and grade IV: dense infiltration of bacteria in all fields. Average points of HP colonisation grade in each group were calculated for statistical purposes.

Histopathologic changes were evaluated as chronic atrophic gastritis, chronic superficial gastritis, chronic ero- 
sive gastritis and acute erosive gastritis. The eradication was described as histologicaly negative examination (grade 0 ).

\section{Statistical analysis}

Student's t test was used for comparison of the age between the groups. Chi square test were used for comparison of results of treatment groups. Spierman test was used for correlation of HP positivity and symptoms. $\mathrm{P}<0.05$ was considered to indicate statistical significance.

\section{Results}

The patient characteristics and distribution of risk factors for gastritis were shown in table 1. There were no statistically significant differences between groups in age, alcohol intake, smoking, non steroidal antiinflammatory drug use and HP positivity.

At the end of the treatment, eradication was achieved in 20 patients $(66.6 \%)$ in group I, 15 patients $(50 \%)$ in

Tab. 1: Patients characteristic.

\begin{tabular}{|l|l|l|l|l|l|l|l|}
\hline $\begin{array}{l}\text { Group/ } \\
\text { Characteristic }\end{array}$ & $\begin{array}{l}\text { Group I } \\
\mathrm{N}=30(\%)\end{array}$ & $\begin{array}{l}\text { Group II } \\
\mathrm{N}=30(\%)\end{array}$ & $\begin{array}{l}\text { Group III } \\
\mathrm{N}=30(\%)\end{array}$ & $\begin{array}{l}\text { Group IV } \\
\mathrm{N}=30(\%)\end{array}$ & $\begin{array}{l}\text { Group V } \\
\mathrm{N}=30(\%)\end{array}$ & $\begin{array}{l}\text { Group VI } \\
\mathrm{N}=30(\%)\end{array}$ & $\begin{array}{l}\text { Group VII } \\
\mathrm{N}=30(\%)\end{array}$ \\
\hline Age (year) & $38.9 \pm 10$ & $40 \pm 10$ & $39 \pm 10$ & $41 \pm 10$ & $38 \pm 10$ & $37 \pm 10$ & $40 \pm 13$ \\
\hline Sex (F/M) & $18 / 12$ & $16 / 14$ & $18 / 12$ & $14 / 16$ & $16 / 14$ & $15 / 15$ & $16 / 14$ \\
\hline Smoking (+/-) & $7 / 23$ & $7 / 23$ & $9 / 21$ & $8 / 22$ & $8 / 22$ & $8 / 22$ & $5 / 25$ \\
\hline Alcohol (+/-) & $-/ 30$ & $5 / 25$ & $5 / 25$ & $4 / 26$ & $5 / 25$ & $6 / 24$ & $2 / 28$ \\
\hline NSAID (+/-) & $7 / 23$ & $8 / 22$ & $6 / 24$ & $4 / 26$ & $3 / 27$ & $4 / 26$ & $4 / 26$ \\
\hline
\end{tabular}

\section{F: Female}

M: Male

(+/-): used or not used

NSAID: Non Steroidal Anti Inflammatory Drugs. There was no statistically difference between the groups, P>0.05.

Tab. 2: At the end of the treatment eradication rates.

\begin{tabular}{|c|c|c|c|c|c|c|c|}
\hline $\begin{array}{l}\text { Group/ } \\
\text { Characteristic }\end{array}$ & $\begin{array}{l}\text { Group I } \\
\mathrm{N}=30(\%)\end{array}$ & $\begin{array}{l}\text { Group II } \\
\mathrm{N}=30(\%)\end{array}$ & $\begin{array}{l}\text { Group III } \\
\mathrm{N}=30(\%)\end{array}$ & $\begin{array}{l}\text { Group IV } \\
\mathrm{N}=30(\%)\end{array}$ & $\begin{array}{l}\text { Group V } \\
\mathrm{N}=30(\%)\end{array}$ & $\begin{array}{l}\text { Group VI } \\
\mathrm{N}=30(\%)\end{array}$ & $\begin{array}{l}\text { Group VII } \\
\mathrm{N}=30(\%)\end{array}$ \\
\hline Eradication (+) & $20(66.7)$ & $15(50)$ & $3(10)$ & $15(50)$ & $-(0)$ & $27(90)$ & $7(24.4)$ \\
\hline Eradication (-) & $10(33.3)$ & $15(50)$ & $27(90)$ & $15(50)$ & $30(100)$ & $3(10)$ & $23(76.6)$ \\
\hline
\end{tabular}

P: value for eradication rates: Group I and II, IV >0.05, Group I and III, <0.001, Group I and VI, VII <0.01.

Tab. 3: Density of HP colonisation before and after treatment.

\begin{tabular}{|c|c|c|c|c|c|c|c|}
\hline $\begin{array}{l}\text { Group/ } \\
\text { Characteristic }\end{array}$ & $\begin{array}{l}\text { Group I } \\
\mathrm{N}=30(\%)\end{array}$ & $\begin{array}{l}\text { Group II } \\
\mathrm{N}=30(\%)\end{array}$ & $\begin{array}{l}\text { Group III } \\
\mathrm{N}=30(\%)\end{array}$ & $\begin{array}{l}\text { Group IV } \\
\mathrm{N}=30(\%)\end{array}$ & $\begin{array}{l}\text { Group V } \\
\mathrm{N}=30(\%)\end{array}$ & $\begin{array}{l}\text { Group VI } \\
\mathrm{N}=30(\%)\end{array}$ & $\begin{array}{l}\text { Group VII } \\
\mathrm{N}=30(\%)\end{array}$ \\
\hline \multicolumn{8}{|c|}{ HP colonisation before treatment } \\
\hline 1 point & 1 & - & 3 & 1 & 4 & 1 & 5 \\
\hline 2 points & 9 & 10 & 16 & 12 & 12 & 14 & 15 \\
\hline 3 points & 14 & 15 & 10 & 13 & 13 & 13 & 10 \\
\hline 4 points & 6 & 5 & 1 & 4 & 1 & 2 & - \\
\hline Aver.points & 2.8 & 2.8 & 2.3 & 2.3 & 2.5 & 2.5 & 2.2 \\
\hline \multicolumn{8}{|c|}{ HP colonisation after treatment } \\
\hline Negative & 23 & 2 & 1 & 24 & - & 29 & 8 \\
\hline 1 point & 7 & 8 & 10 & 6 & 4 & - & 22 \\
\hline 2 points & - & - & 12 & - & 13 & 1 & - \\
\hline 3 points & - & - & 7 & - & 13 & - & - \\
\hline 4 points & - & - & - & - & - & - & - \\
\hline Aver.points & 0.23 & 0.26 & 1.83 & 0.20 & 2.30 & 0.06 & 0.73 \\
\hline
\end{tabular}

$\mathrm{P}$ values for average points before treatment: There was no statistically difference between the groups.

$P$ value for average points after treatment: Group I and II, IV >0.05, Group I and III, <0.001, Group I and VI, VII <0.01. 
group II, 3 patients ( $10 \%$ ) in group III, 15 patients ( $50 \%$ ) in group IV, 0 patients $(0 \%)$ in group V, 27 patients $(90 \%)$ in group VI and 7 patients $(23.3 \%)$ in group VII. The eradication rates were compared with standard treatment group. There was no statistically significant difference between group I and II, IV, VI. Eradication rates in group VI and VII were higher and the differences were statistically significant $(\mathrm{p}<0.001, \mathrm{p}<0.001, \mathrm{p}<0.01$ respectively $)$. In group III eradication rate was significantly low. No eradication was achieved in group $\mathrm{V}$.

To assess the efficiencies of drug therapies beyond the cases in which complete eradication has achieved we compared average points of HP colonisation grade before and after treatment in each group. The findings were given in table 3. Rates of reduction in HP colonisation were similar to eradication rates in all groups. There were no additional adverse effects with the use of AA, BC and Allicin in combination with standard regiment. Monotherapy of these agents tolerated well also.

\section{Discussion}

Despite numerous studies on HP eradication there is not an accepted golden standard treatment regiment yet. In most studies two or three antimicrobial agents in combination with proton pump inhibitors were shown to be most effective. In previous studies clarithromycin, amoxicillin and lansaprosol combination were shown to eradicate HP in $60 \%-96 \%$ of cases and accepted as one of the most successful regiments $(11,16)$. On the other hand emerging antibiotic resistance, high treatment costs and drugs side effects necessitates development of new treatment modalities.

HP induces infiltration of the gastric mucosa by polymorphonuclear cells and macrophages, as well as $\mathrm{T}$ and B lymphocytes $(2,6)$. Paradoxically, this strong immune/inflammatory response cannot clear the infection, and thus leaves the host prone to complications resulting from chronic inflammation. The attracted immune cells produce inflammatory mediators that include reactive oxygen species (ROS). These mediators impart an oxidative stress on the cells in the immediate vicinity in the gastric epithelium (15). Normally, oxidative stress is neutralized by natural antioxidants such as vitamin C, beta carotene (4). However, levels of this antioxidant in the gastric juice are decreased during HP infection $(2,7,13,19,25)$. On the other hand vita$\min \mathrm{C}$ is shown to be bactericidal for HP in vitro. In a clinical study high dose vitamin $\mathrm{C}$ ( $5 \mathrm{~g} /$ day for four weeks) successfully eradicated eight of 27 patients (30\%) (10). In our study, vitamin $\mathrm{C}$ treatment for shorter period (14 days) with a lower dose ( $1 \mathrm{~g} /$ day) was effective in only three of (10\%) 30 cases. Vitamin $C$ appears to be not an agent powerful enough to be used in eradication alone. On the other hand addition of vitamin $\mathrm{C}$ to standard regiment did not improved the eradication rates contrary to our expectations.

Similar to vitamin $\mathrm{C}$ gastric juice beta-carotene concentration was shown to be markedly lower in patients in- fected with HP $(10,20)$. Beta carotene was thought to act as a mucosal protector by scavenging the ROS (20). The authors did not encounter any previous clinical study that beta carotene had been used in HP treatment. In our study beta carotene treatment ( $120 \mathrm{mg} /$ day for 14 days) - either alone or in combination with the standard regiment - was disappointingly ineffective.

Garlic extracts have in vivo and in vitro anti HP activity (17). Many studies have been conducted on anti-HP activity of garlic extracts $(21,24)$. Relative activities of garlic powder, garlic oil, diallyl sulphide and Allicin had been studied and Allicin was found to be most potent garlic ingredient (20). MIC of Allicin was 4.0 microgram $/ \mathrm{ml}$. The antibacterial activity of garlic was also studied after combination with a proton pump-inhibitor (omeprazol) and a synergistic effect was found $(5,14)$. Chronic HP disease is reduced with Allium vegetable intake. Graham et al. studied effect of fresh garlic in eradication of HP (8). They used three test meals and measured urease activity by a breath test. The authors concluded that garlic was not effective in vivo. Aydin et al. used garlic oil $275 \mathrm{mg}$ capsules containing 800 $\mu \mathrm{g}$ Allicin t.i.d. and garlic oil capsules plus omeprazol 20 $\mathrm{mg}$ /day for two weeks in two patient groups, each consisting of ten patients (1). They found that grade of gastritis and HP density were unchanged in all cases. In our study, we used $1200 \mu \mathrm{g} /$ day Allicin for two weeks in two groups, each consisting 30 patients. It is the first study that Allicin was used in combination with standard eradication regiment. Also Allicin dose was higher than the previous studies. Addition of Allicin increased the eradication rate in standard regiment group from $66.7 \%$ to $90 \%$. In patients taking only Allicin eradication was achieved in $24.4 \%$. Our study, supports the hypothesis derived from in vitro studies that Allicin can be used in HP eradication. It is particularly advisable to combine Allicin with standard therapies. The effect may be dose related hence use of higher doses can be warranted. Allicin may help to overcome drug failure which was very high in our standard treatment group.

\section{Conclusions}

Ascorbic acid and beta carotene was found to be ineffective in HP eradication in vivo. On the other hand Allicin seemed to be potentially effective against HP in vivo.

\section{References}

1. Aydin A, Ersoz G, tekesin O, Akcicek E, Tuncyurek M. Garlic oil and Helicobacter pylori infection. Am J Gastroenterol 1999;94:1200-2.

2. Bennedsen M, Wang X, Willen R, Wadstron T, Andersen LP. Treatment of H. pylori infected mice with antioxidant astaxanthin reduces gastric inflammation, bacterial load and modulates cytokine release by splenocytes. J. gastroenterol Hepatol 1999;12:73-82.

3. Drouin E. Helicobacter pylori : novel therapies. Antimicrob Agents Chemother 1999;43:1811-2

4. Ekstrom AM, Serafini M, Nyren O, Hansson LE, Ye W, Wolk A. Dietary antioxidant intake and the risk of cardia cancer and noncardia cancer of the intestinal and diffuse types: a po;ulation-based case-control study in Sweden. Immunol Lett 1999;70:185-9. 
5. Ernst E. Is garlic an effective treatment for Helicobacter pylori infection? Am J Gastroenterol 2000;95:309.

6. Ernst P. The role of inflammation in the pathogenesis of gastric cancer. Eur J Cancer Prev 1998; 7:449-54.

7. Fraser AG, Woollard GA. Gastric juice ascorbic acid is related to Halicobacter pylori infection but not ethnicity. Indian J Gastroenterol 1999;18:129-30.

8. Graham DY, Anderson SY, Lang T. Garlic or jalapeno peppers for treatment of Helicobacter pylori infection. Int J Epidemiol 1989;27:941-4.

9. Guidelines for clinical trials in Helicobacter pylori infection. Gut 1997;41:521-3.

10. Hep A, Pospisilova J, Dolina J, Prasek J, Dite P. Levels of vitamins A,E and C in serum and gastric juice in relation to gastric mucosa and occurrence of Helicobacter pylori. Pharmacol Ther 1998;12:73-82.

11. Hopkins RJ, Girardi LS, Turney EA. Relationship between Helicobacter pylor eradication and reduced duodenal and gastric ulcer recurrence. Gastroenterology 1996;110:1244-52.

12. International Agency for Research on Cancer. World Health Organization Infection with Helicobacter pylori. Lyon: IARC ,1994:177-202.

13. Jarosz M, Dzieniszewski J, Dabrowska-Ufniarz E, Wartanowicz M, Ziemlanski S, Reed PI. Effects of high dose vitamin C treatment on Helicobacter pylori infection and total vitamin C concentration in gastric juice. Gut 1998;43:322-6.

14. Jonkers D, van den Broek E, van Dooren I et al. Antibacterial effect of garlic and omeprazole on Helicobacter pylori. Am J Gastroenterol 1999;94;1200-2.

15. Nair S, Norkus EP, Hertan H, Pitchumoni CS. Micronutrient antioxidants in gastric mucosa and serum in patients with gastritis and ulcer: does Helicobacter pylori infection affect the mucosal levels? Int J Cancer 2000;87:133-40.

16. NIH. Medical treatment of peptic ulcer disease. JAMA 1996;275:622-8.

17. O'Gara EA, Hill DJ, Maslin DJ. Activities of garlic oil, garlic powder, and their diallyl constituents against Helicobacter pylori. Am J Gastroenterol 2000;95:820-1.

18. Parsonnet J. Helicobacter pylori and gastric cancer. Gastroenterol Clin N Am 1993;122:89-104
19. Phull PS, Price AB, White KL, Schorah CJ, Jacyna MR. Gastroduodenal mucosal vitamin-C levels in Helicobacter pylori infection. Nutrition 1999;15:402-3.

20. Sanderson MJ, White KL, Drake IM, Schorah CJ. Vitamin E and carotenoids in gastric biopsies: the relation to plasma concentrations in patients with and without Helicobacter pylori gastritis. J Adolesc Health 1994;15:205-9.

21. Sivam GP, Lampe JW, Ulness B, Swanzy SR, Potter JD. Helicobacter pylori - in vitro susceptibility to garlic (Allium sativum) extract. Nippon Shokakibyo Gakkai Zasshi 1996;193:688.

22. Telford JL, Ghiara P, Dell Orco M et al. Gene structure of the Helicobacter pylori cytotoxin and evidence of its key role in gastric disease. J Exp Med 1994;179:1653-8

23. Waring AJ, Drake IM et al. Ascorbic acid and total vitamin $\mathrm{C}$ concentrations in plasma, gastric juice, and gastrointestinal mucosa: effects of gastritis and oral supplementation. Gut 1996;38:171-6.

24. Wong RM, Kondo Y, Banba H, Matsuzaki S, Sekine S. Anti-Helicobacter pylori activity in the garlic extract. FEMS Immunol Med Microbiol 1996;13:273-7.

25. Zhang ZW, Patchett SE, Perrett D, Katelaris PH, Domizio P, Farthin MJ. The ralation between gastric vitamin $\mathrm{C}$ concentrations, mucosal histology, and CagA seropositivity in the human stomach. Dig Dis Sci 1998;43:192-7.

Submitted June 2001.

Accepted November 2001.

Dr. Nüket Bavbek,

Harbiye Mahallesi Niğde Sokak, No: 46/2 TR-06460, Dikmen Ankara, Turkey. e-mail: ntbavbek@yahoo.com 